19. Sistema kontrolya bobin. Automatic bobbin laser inspector // International textil Buletin. Chemiefasern-textilindustrie. 1997. Vol. 47. No. 4. P. 304

20. Sistema kontrolya pakovok. New laser inspection system for POY and DTY packages // Text. Technol. Dig. 1996. Vol. 53. No. 6. Pt. 2. P. 90

21. Kuchin A. A., Obradovich K. A. Opticheskie pribory dlya izmereniya sherokhovatosti poverkhnosti. Leningrad: Mashinostroenie. 1981. 197 p.

22. Programmnoe obespechenie dlya postroeniya trekhmernoy modeli pakovki / Kiselev P. N. // Vestnik Kostromskogo gosudarstvennogo tekhnologicheskogo universiteta (KGTU). 2004. Vol. 9. P. $87-89$

23. Rudowskij P. N. Kontrole des spulenaufbau bei wilder wicklung // Melliand Textilberichte. 1997. No. 3. P. 138.

24. Development of a Device for Continuously Monitoring the Parameters of the Winding Structure of Textile Bobbins / Nuraddin-Nuriyev M. et al. // Ingeniería Solidaria. 2018. Vol. 14 No. 24. P. 1-15.
Nuriyev Mahamadali, Doctor of Technical Sciences, Professor, Department of Standardization and Certification, Azerbaijan State Economic University (UNEC), Baku, Azerbaijan, ORCID: http:// orcid.org/0000-0002-6729-4627, e-mail: mehman62@mail.ru

Seydaliyev Ilham, PhD, Associate Professor, Department of Standardization and Certification, Azerbaijan State Economic University (UNEC), Baku, Azerbaijan, ORCID: http://orcid.org/00000002-7323-2318,e-mail: ilham.seydaliyev@mailru

Dadashova Kamala, PhD, Senior Lecturer, Department of Standardization and Certification, Azerbaijan State Economic University (UNEC), Baku, Azerbaijan, ORCID: http://orcid.org/00000001-6803-1274, e-mail: kamale.dadasheva.74@mail.ru

Jabbarova Ganira, Lecturer, Department of Consumer Goods Expertise, Azerbaijan State Economic University (UNEC), Baku, Azerbaijan, ORCID: http://orcid.org/0000-0002-1718-9976, e-mail: qenire.cabbarova@mail.ru

DOI: 10.15587/2312-8372.2018.135773

\section{Panchenko V., Ivchenko A., Dynnyk 0. Drach 0.}

\title{
INCREASING THE TECHNICAL LEVEL OF A TOROUE FLOW PUMP BY CHANGING THE GEOMETRY OF A FLOWING PART
}

Об'єктом дослідження є насос динамічного принщипу дї, а саме вільновихровий насос типу «TURO» (Швейцарія).

Основним недоліком вільновихрових насосів є більш низьке значення коефічієнту корисної дї̈ порівняно $з$ відцентровими насосами. Це пояснюється особливістю їх робочого процесу - утворення у вільній камері насоса поздовжнього вихору, на підтримання якого й витрачається частина споживаної насосом потужності.

Аналіз апріорної інформацї свідчить про доцільність використання зміни геометрї проточної частини насоса як способу впливу на його напірну та енергетичну характеристику. Видовження частини лопатей робочого колеса у вільну камеру дозволяє використати у насосі комбінований робочий процес (лопатевий та вихровий), що дозволить підвищти економічність насоса без втрати ним істотних переваг, притаманним насосам даного типу.

Виготовлені експериментальні робочі колеса та проведене випробування на дослідному стенді. Отримані результати свідчать про можливість підвищення напору та коефічієнту корисної дї насоса при збереженні місцезнаходження оптимального режиму.

Визначена номенклатура показників якості, за якими проводиться порівняння створеного насосу та насосу-аналогу. Обрано метод Харінгтона (метод «бажаної функцї̈») для визначення базового показника якості. Визначено коефічієнти вагомості для показників якості і розраховано інтегральний показник технічного рівня створеного насосу та насосу-аналогу.

Обгрунтовано використання SST-моделі турбулентності для проведення числового моделювання течї у проточній частині вільновихрового насоса. Проведено числовий розрахунок та отримано інтегральні показники насоса.

Запропонована конструкиія дозволяє створити нове насосне обладнання з покращеними показниками та більш високим технологічним рівнем або підвищити відповідні показники існуючого обладнання шляхом внесення змін у конструкцію робочого колеса. Вказані зміни не вимагають значних витрат та не потребують використання складного обладнання і можуть бути реалізовані безпосередньо на місиі експлуатаціі власними силами підприємства чи експлуатуючої організації.

ключові слова: вільновихровий насос, робоче колесо, технічний рівень, модель турбулентності.

\section{Introduction}

Torque flow pumps (Fig. 1) is a type of pumping equipment with an easy-to-use design and provide high reliability, durability and economic efficiency when working on pumps. They are also used in the transport of various solids and products [1-3].
Analysis of the components of the pumping equipment and the main trends of the pump market development lifecycle point advantage torque flow pumps (TFP) [1] during transfer:

- liquids with a high content of abrasive particles;

- suspensions with a high solids content and fibrous impurities: 
- liquids with increased density;

- liquids with a high content of air or gas [4];

- fluids sensitive to slice;

- liquids containing brittle substances, and also ensure unimpeded and continuous transport of fibrous suspensions [5].

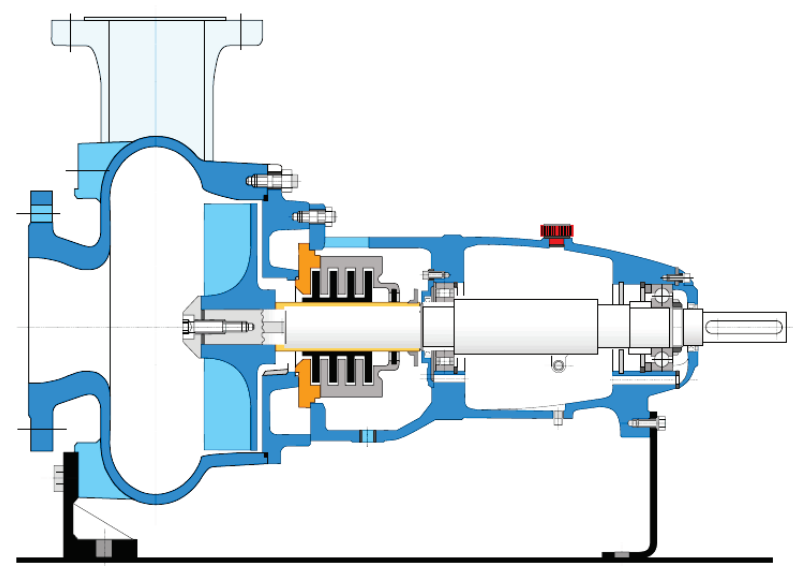

Fig. 1. Torque flow pump of the «Tura» type from EGGER (5witzerland)

These pumps are designed to work in conditions in which centrifugal pumps can't work or their operation is unreliable. It is emphasized that in addition to the advantages TFP have disadvantages, the main of which is a low efficiency (pump efficiency is $\eta=0.38-0.58$ ). However, despite the low efficiency, TFP use has a significant economic effect.

Therefore, it is relevant to study the TFP working process, aimed at increasing their efficiency.

\section{The object of research and its technological audit}

The object of research is a dynamic pump of the torque flow principle of action.

In the process of TFP creation, three basic designs of these pumps have been developed, which differ in the form of the impeller (I), the retraction and the location of the wheel relative to the free chamber: Wemco, Turo and Seka.

The first was a «Wemco» type TFP, developed in the USA in 1954 by the Western Machinery Company. The impeller of this pump is made according to the example of a hydraulic coupling wheel and is placed in the bore of the rear wall of the casing. The disadvantage of TFP of this type is a low efficiency, which is $30-40 \%$ [6].

Further studies of various TFP designs to increase head and efficiency led to the creation of a new type of pump - the «Turo» design of EGGER (Switzerland). In this scheme, the impeller is made in the form of a disk with straight radial blades (open or closed on the periphery). In this pump, a sudden change in the direction of movement of the liquid when exiting the impeller in the axial direction intensifies the energy exchange between the fluid streams emerging from the wheel and enters the free chamber [1]. This gives an increase in head and efficiency (the efficiency of the «Turo» pump reaches a level of $54-58 \%$ ). In practice, the principle of the «Turo» pump became famous in 1958 in the USA. The structural feature of this pump is that the rotor is completely pushed back into the bore of the rear of the casing. Thanks to this, all the inner space of the body remains free before the rotor. The impeller blades in addition to the radial ones, can be bent in the direction opposite to its rotation.

The basis of the «Seka» pumps is the principle of extending the impeller to the enclosure niche into a free chamber, which increases the proportion of the blade operation and leads to an increase in the head and efficiency of the pump. «Seka» pump is produced by the company «VOGEL» (Austria). The impeller of this pump has no restriction on the periphery and is pushed into the free chamber, and the liquid that leaves the impeller is sent directly to the tap. However, the use of these pumps is limited due to possible clogging of the pumped product, especially during transport of liquids containing fibrous substances.

In addition to these designs, there are several other versions of modified TFP designs that differ in the geometry of the impeller blades, as well as in the size of the extension of the blades into the free chamber. The pump design scheme is chosen taking into account the operating conditions and properties of the pumped liquid.

One of the most problematic places is the low efficiency of the centrifugal pumps.

\section{The aim and objectives of research}

The aim of research is determination of the optimum parameters of the geometry of the flowing part of the torque flow pump in order to increase its technical level.

To achieve this aim, it is necessary to perform the following tasks:

1. To substantiate the choice of the method of influencing the geometry of the TFP flowing part.

2. To perform numerical simulation of the flow of fluid in the TFP flowing part.

3. To conduct a physical experiment on the test bench.

4. To determine the technical level of the TFP new design and compare it with the base one.

\section{Research of existing solutions of the problem}

Let's perform an analysis of earlier studies from possible ways to improve the TFP profitability. Let's dwell on the ways of making changes in the TFP design diagram of «Turo» pump or the impeller design.

In particular, the author of the work [7] investigated the principle of the transition from the design of a centrifugal pump with a semi-open impeller to the TFP design. Explaining the working process of these pumps, he claims that the physical processes in the TFP are similar processes in centrifugal pumps with an open impeller and a large gap between the blades and the hull. At the same time he relies on his research, which shows that the head ratio, which is equal to the ratio of the head to the specific kinetic energy of impeller:

$$
\psi=\frac{H}{u^{2} / 2 g},
$$

where $H$ - head; $u$ - the peripheral speed at the exit from the wheel. That this coefficient, in contrast to previously published data, turned out to be lower than the corresponding head factors for centrifugal pumps. That is, he claims that 
the presence of a circulating flow (longitudinal vortex) in the TFP does not lead to an increase in the head, since this occurs in the vortex pump. Further studies by many authors on the study of the flow structure in TFP do not confirm this analogy [1,2].

Investigations [3, 7] on the effect of the lateral clearance $\mathrm{x}$ between the semi-open impeller and the front wall of the casing in the centrifugal pump indicate that, with a significant increase in clearance, the design of a centrifugal pump with a semi-open impeller goes into the TFP design of the «Seca» type. And further, when the wheel is placed in the boring of the casing - in the TFP design of «Turo» type.

The impeller layout is shown in Fig. 2, $a$. The clearance $x$ in the studies varied from 0.3 to $20 \mathrm{~mm}$. From Fig. 2, $b$, it can be seen that when the gap is increased, the head first sharply (up to $x=2 \mathrm{~mm}$ ), and then gradually decreases and at $x=5 \mathrm{~mm}$ reaches the lower limit. Experiments in the region of large gap values (up to $x=20 \mathrm{~mm}$ ) showed that the drop in head was insignificant. Change in efficiency of the pump is characteristic. The efficiency at the maximum gap $(\mathrm{mm})$ has changed by $2 / 3$ of the original value of efficiency at $x=3 \mathrm{~mm}$, and the head ratio has decreased from $\psi=0.97$ to $\psi=0.69$.
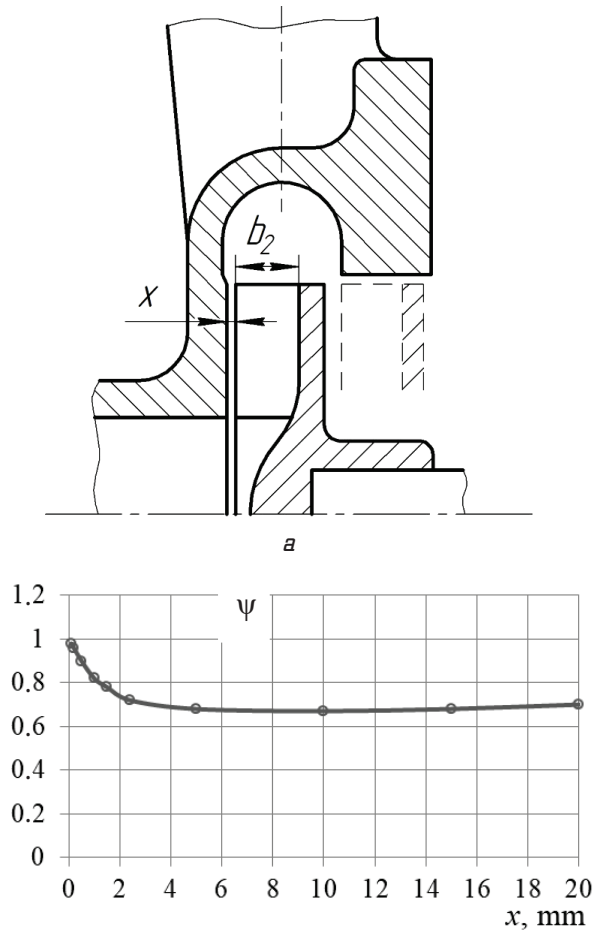

$b$

Fig. 2. The flow pattern of the fluid in the flowing part of the TFP according to the results of the flow calculation [1]: $a$ - flowing part diagram; $b$ - dependence of the pressure ratio on the gap

Such change in the parameters of the pump can be explained by the transition of the design of the centrifugal pump to the torque flow and the fundamental change in the working process. At the same time, the share of the vortex working process grows, which leads to an increase in hydraulic losses in the pump and, as a result, a decrease in head and efficiency.
The analysis and generalization of the results of the authors [8-10] on the impeller extension and its influence on the TFP characteristics make it possible to draw the following conclusion that it can be used as one of the methods for adjusting the parameters of this pump: the supply $Q$ and the head $H$. The impeller extension inside the free chamber allows to raise a head and efficiency of the pump, the maximum values they reach at completely advanced wheel. With an increase in the advance value, the optimum feed value shifts to the right. The increase in efficiency, which is observed when the impeller is extended, can be explained by the fact that in this case the number of cycles of fluid rotation in the free chamber of the pump is reduced, and most of it is sent directly to the tap. This is reflected in the reduction of hydraulic losses in the pump and, as a consequence, the growth of its efficiency. However, it should be noted that the impeller extension into the free chamber worsens the ability of the pump to pump liquids with large and fibrous impurities.

In [11-13], a study was made of the effect of the method of installing TFP impellers relative to the casing in a spiral bend. The results of the experiments show that with an increase in the amount of impeller extension to the free chamber, there are corresponding increases in the head and efficiency of the pump. The authors explain the obtained results by changing the structure of the fluid flow in the TFP flowing part from the actual vortex to that which is close to the flow in centrifugal pumps.

Thus, the results of the analysis allow to conclude that the effect on the geometry of the TFP impeller can increase the efficiency of its operation (increase in efficiency). In addition, there are prospects for expanding the operating parameters of the pump (increasing the head while maintaining optimum flow).

\section{Methods of research}

The analysis and generalization of the results on the impeller extension and its impact on the TFP characteristics allow to draw the following conclusions. The impeller extension of the TFP liquid can be used as one of the ways to adjust the parameters of this pump: the supply $Q$ and the head $H$. As follows from Fig. 3 [1], extending the $L C$ inside the free chamber allows to increase the head and efficiency of the pump, the maximum values (according to the experiment $\bar{H}=1.15, \eta=0.535$ ), they reach with the wheel fully extended. Here

$$
\bar{H}=\frac{7200}{\pi^{2}} \cdot \frac{g H}{n^{2} D_{2}^{2}}, \quad \bar{Q}=\frac{240}{\pi^{2}} \cdot \frac{Q}{n D_{2}^{3}},
$$

where $n$ - the frequency of rotation, rpm.

With an increase in the advance value, the optimum feed value shifts to the right. The increase in efficiency, which is observed when the impeller is extended, can be explained by the fact that in this case the number of cycles of fluid rotation in the free chamber of the pump is reduced, and most of it is sent directly to the tap. This is reflected in the reduction of hydraulic losses in the pump and, as a consequence, the growth of its efficiency.

However, it should be noted that the impeller extension into the free chamber worsens the ability of the pump to pump liquids with large and fibrous impurities. 

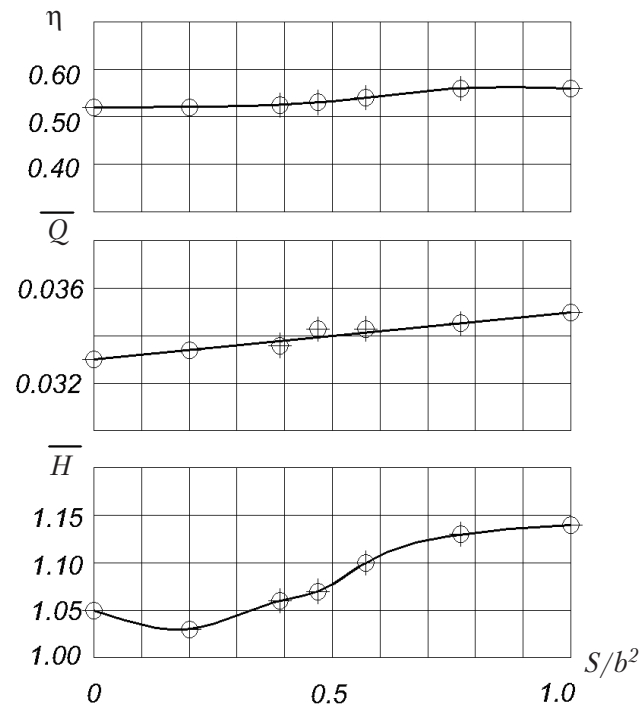

Fig. 3. Influence of impeller extension to the free chamber on the TFP characteristics

In order to increase the pressure and efficiency in the «Turo» pumps, impeller was made with blades that have no periphery of the performance (Fig. 4), located in a free chamber and forming an axial gap with the casing.

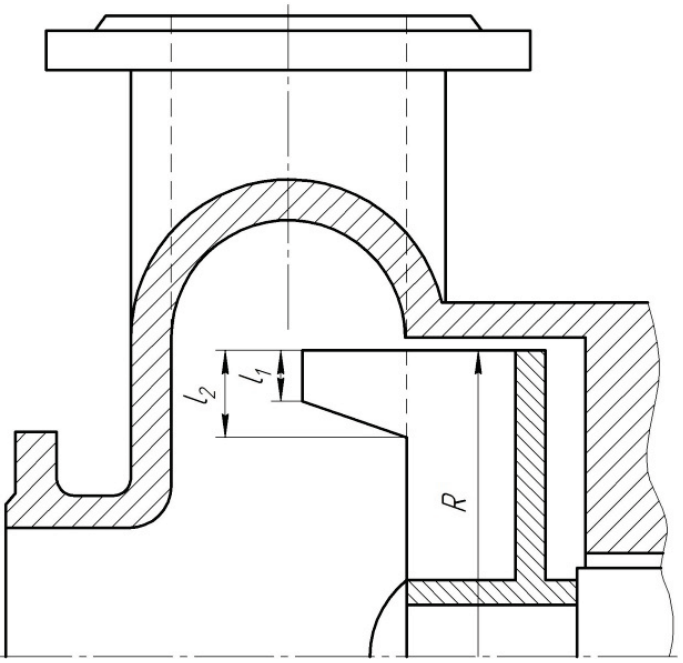

Fig. 4. TFP impeller with performances in the free chamber [14]

5.1. Physical experiment. In order to increase the TFP technical level, it is proposed to push only a part of the impeller blades into the free chamber of the pump, which would increase the head and efficiency with practically no effect on the maximum size of pumped impurities. Thus, a design is created that realizes a combined (blade and vortex) working process and is a transitional form between the wellknown TFPs and centrifugal pumps with a semi-open impeller.

For testing, a special test stand was created, which operates according to a scheme with a closed loop of water circulation. The basic hydraulic scheme of the experimental bench is shown in Fig. 5 .

Its main equipment included:

- experimental pump P;

- balancing DC machine with a power M up to $24.5 \mathrm{~kW}$ and a speed of $0-4500 \mathrm{rpm}$;
- hermetically sealed tank T with a capacity of $20 \mathrm{~m}^{3}$; - flowmeter narrowing device FM with differential pressure manometer MD. The flowmeter device consists of a diaphragm and pipeline sections of a certain length according to [15]. Also in the experimental stand included: control panels, main and auxiliary pipelines, measuring equipment (manometers M1, M2, vacuum gage $\mathrm{V}$, tachometer $\mathrm{TH}$, thermometer $\mathrm{T}$ ) and control equipment (throttles T1-T5, valves V1, V2) equipment.

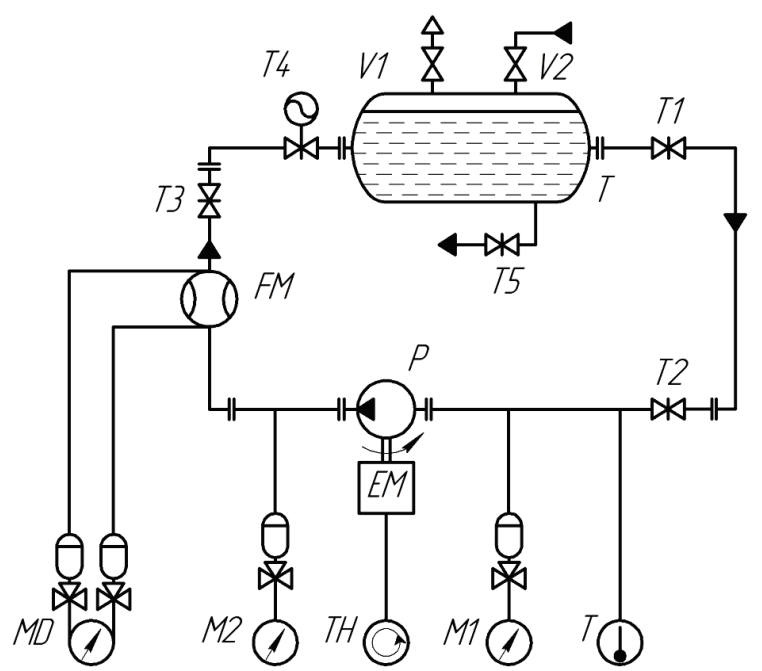

Fig. 5. Hydraulic scheme of the experimental bench: T - tank; V1-2 - valves; T1-T5 - throttles; M1-M2 - manometers; MD - differential pressure manometer; P - pump; FM - flowmeter; TH - tachometer; T - thermometer; EM - electric motor

The measuring equipment provided the possibility of removing the pressure, energy and cavitation characteristics of the model pump in accordance with [16]. During the experimental tests, water with characteristics according to [17] was used as the working medium.

Experimental pump of cantilever type with axial supply of working fluid. The pump casing has a tangential outlet. The impeller is located in the recess of the casing. The pump shaft is sealed with an oil seal. Roller bearings are lubricated with rolling bearings. The impeller, which part of the blades is extended into the free chamber, is installed in the bore of the casing (Fig. 6).

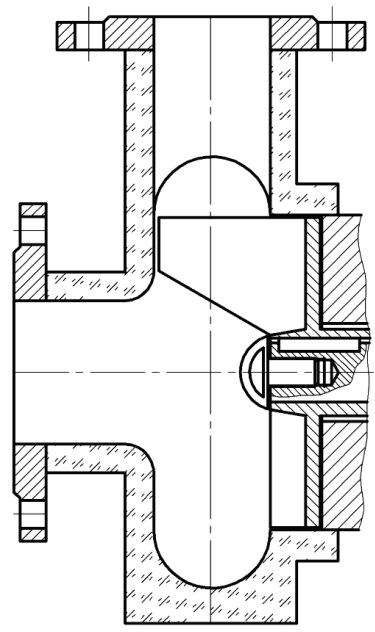

Fig. 6. Impeller in the pump casing 
5.2. Numerical experiment. The numerical study of flow in the flowing part of the TFP structure was conducted using the software product (ANSYS Academic Research CFD 12.1.

The basis of the state of emergency on the method of numerical solution of the fundamental laws of hydromechanics [18]: the equations of motion of a viscous fluid with the equation of continuity, ensures the validity of the application of the results of numerical studies.

The software product using ANSYS finite volume method which comprises sampling the spatial domain using a computational grid. The grid is used to construct finite volumes that carry the properties of conservation of mass, momentum, and energy. In this problem, a three-dimensional grid is used. For simplicity of illustration let's use a twodimensional grid.

Fig. 7 shows a typical two-dimensional grid. All variables and fluid properties are stored in nodes (cell vertices). Control volumes (the shaded area) are built around each grid node using double medians.

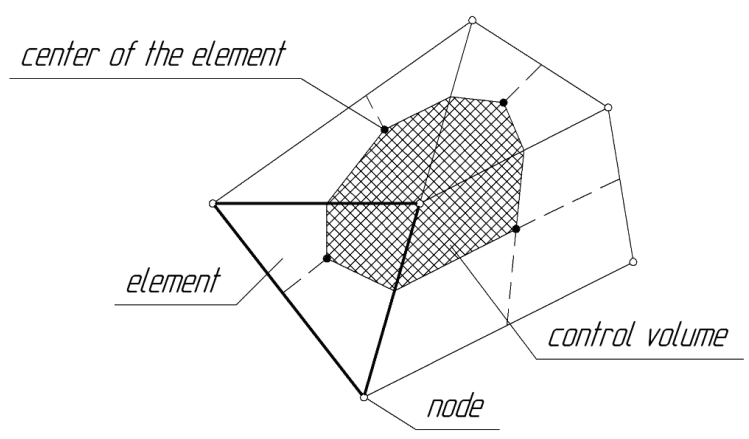

Fig. 7. Illustration of the finite volume method

To illustrate the finite volume method, let's write the equations of conservation of masses, moments and energy in a cylindrical coordinate system:

$$
\begin{aligned}
& \frac{\partial p}{\partial t}+\frac{\partial}{\partial x_{j}}\left(\rho U_{j}\right)=0, \\
& \frac{\partial}{\partial t}\left(\rho U_{j}\right)+\frac{\partial}{\partial x_{j}}\left(\rho U_{j} U_{i}\right)= \\
& =-\frac{\partial P}{\partial x_{i}}+\frac{\partial}{\partial x_{j}}\left(\mu_{e f f}\left(\frac{\partial U_{i}}{x_{j}}+\frac{\partial U_{j}}{x_{i}}\right)\right), \\
& \frac{\partial}{\partial t}(\rho \varphi)+\frac{\partial}{\partial x_{j}}\left(\rho U_{j} \varphi\right)=\frac{\partial}{\partial x_{j}}\left(\Gamma_{e f f}\left(\frac{\partial \varphi}{\partial x_{j}}\right)\right)+S_{\varphi},
\end{aligned}
$$

where $p$ - hydrodynamic pressure; $x_{j}$ - Cartesian coordinates; $u_{j}$ - projections of speed in the Cartesian coordinate system; $\mu_{e f}=\mu+\mu_{t}-$ effective viscosity; $\mu_{t}-$ turbulent viscosity; $\mu$ - molecular viscosity; $t$ - time.

These equations are integrated for each control volume. To transform the volume integrals associated with the divergence and the gradient of the surface integral operators, the Gauss divergence theorem is applied. If the control volumes do not deform with time, then the time derivative can be moved beyond the limits of volume integrals, then the system of integral equations can be represented as:

$$
\begin{aligned}
& \frac{d}{d t} \int_{V} \rho \mathrm{d} V+\int_{S} \rho U_{j} \mathrm{~d} n_{j}=0, \\
& \frac{d}{d t} \int_{V} \rho U_{i} \mathrm{~d} V+\int_{S} \rho U_{j} U_{i} \mathrm{~d} n_{j}= \\
& =-\int_{S} P \mathrm{~d} n_{j}+\int_{S} \mu_{e f f}\left(\frac{\partial U_{i}}{\partial x_{j}}+\frac{\partial U_{j}}{\partial x_{i}}\right) \mathrm{d} n_{j}+\int_{V} S_{U_{i}} \mathrm{~d} V, \\
& \frac{d}{d t} \int_{V} \rho \varphi \mathrm{d} V+\int_{S} \rho U_{j} \varphi \mathrm{d} n_{j}=\int_{S} \Gamma_{e f f}\left(\frac{\partial \varphi}{\partial x_{j}}\right) \mathrm{d} n_{j}+\int_{V} S_{\varphi} \mathrm{d} V,
\end{aligned}
$$

where $V$ and $S$ respectively denote the volume and surface regions of integration, and $d n_{j}$ is the differential component of the external normal vector to the surface in the Cartesian coordinate system. Integrals by volume are a source or set of conditions, surface integrals are summation of flows.

The next step of the numerical algorithm is the discretization of volume and surface integrals. To illustrate this step, let's consider a single element, as shown in Fig. 8.

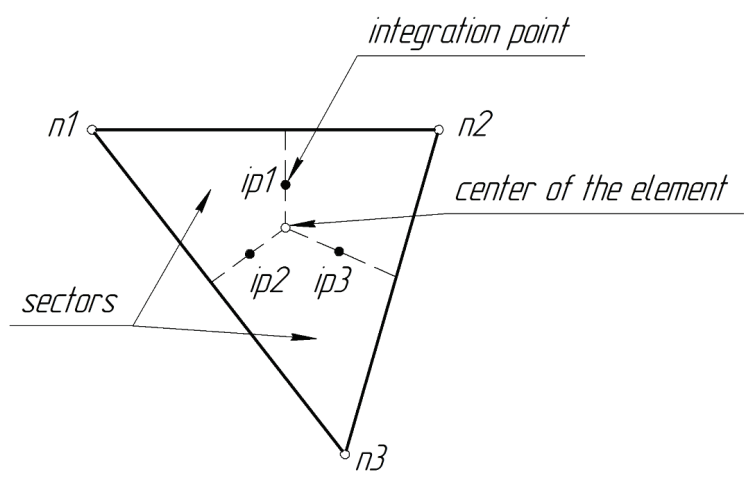

Fig. 8. The grid element

Volumetric integrals are discretized within each element of the sector and accumulate in the control volume to which the sector belongs. Surface integrals are discretized at integration points $\left(i p_{n}\right)$ located at the center of the surface of each segment within the element, and then distributed in adjacent control volumes. Since the surface integrals are equal and opposite in control volumes adjacent to the integration points, the surface integrals will be guaranteed to be locally conservative.

After discretizing the volume and surface integrals, the integral equations become:

$$
\begin{aligned}
& V\left(\frac{\rho-\rho^{\circ}}{\Delta t}\right)+\sum_{i p} \dot{m}_{i p}=0, \\
& V\left(\frac{\rho U_{i}-\rho^{\circ} U_{i}^{\circ}}{\Delta t}\right)+\sum_{i p} \dot{m}_{i p}\left(U_{i}\right)_{i p}=\sum_{i p}\left(P \Delta n_{i}\right)_{i p}+ \\
& +\sum_{i p}\left(\mu_{e f f}\left(\frac{\partial U_{i}}{\partial x_{j}}+\frac{\partial U_{j}}{\partial x_{i}}\right) \Delta n_{j}\right)_{i p}+\bar{S}_{\varphi} V, \\
& V\left(\frac{\rho \varphi-\rho^{\circ} \varphi^{\circ}}{\Delta t}\right)+\sum_{i p} \dot{m}_{i p} \varphi_{i p}=\sum_{i p}\left(e f f \frac{\partial \varphi}{\partial x_{j}} \Delta n_{j}\right)_{i p}+\bar{S}_{\varphi} V,
\end{aligned}
$$


where $\dot{m}_{i p}=\left(\rho U_{j} \Delta n_{j}\right)_{i p}, V-$ the control volume, $\Delta t-$ the time step, $\Delta n_{j}$ - the discrete vector of the outer normal to the surface, the index «ip» means the points of integration over which summation occurs in the reference volume, and the designation $~^{\circ} »$ refers to the previous time level. In this scheme, the inverse Euler scheme of the first order is applied.

The calculation of the flow was performed by numerically solving a system of equations describing the most general case of motion of a liquid medium - the NavierStokes equations and the continuity equation. Simulation of turbulent flows was performed using the Reynolds equations, for the closure of which a number of turbulence models are used in this particular state of emergency.

Previous studies [19] show that for the calculation of the flow in the TFP, it is most expedient to use the SST model of turbulence.

The most common among the differential models of turbulence is the two-parameter model, based on the consideration of the kinetic energy of turbulent pulsations $k$. As the second equation, they use the equations of transport of the energy dissipation rate $\varepsilon$ or the equation of the specific energy dissipation rate $\omega$. The difference in the models consists in taking into account the influence of the wall when calculating wall currents. Models of turbulence of the $k-\varepsilon$ type with a high degree of reliability describe the flow at a distance from the wall, and models of the $k-\omega$ type have an advantage in modeling nearwall currents. The SST turbulence model combines the best properties of the specified models, since it includes a special function that is responsible for switching from one turbulence model to another.

A full list of the possibilities of this emergency, which is the basis of the mathematical apparatus and basic models of hydrodynamics, can be found in the documentation for this emergency [20,21]. In addition, a significant number of publications have been devoted to this issue [22-25].

The calculation is carried out in a stationary setting. The working medium (water under normal conditions) is considered incompressible, the flow regime is turbulent.

The mathematical model used in the calculations is based on the system of equations for the conservation of momentum and mass, and the SST model:

$$
\begin{aligned}
& \frac{\partial u_{i}}{\partial t}+u_{j} \frac{\partial u_{i}}{\partial x_{j}}=F_{i}-\frac{1}{\rho} \frac{\partial p}{\partial x_{i}}+\frac{\partial}{\partial x_{j}}\left[\frac{\mu_{e f}}{\rho} \frac{\partial u_{i}}{\partial x_{j}}\right] ; \\
& \frac{\partial u_{i}}{\partial x_{i}}=0 ; \\
& \frac{\partial(\rho k)}{\partial t}+\frac{\partial}{\partial x_{j}}\left(\rho u_{j} k\right)=\frac{\partial}{\partial x_{j}}\left(\mu_{e f} \frac{\partial k}{\partial x_{j}}\right)+P_{k}-\beta^{*} \rho k \omega ; \\
& \frac{\partial(\rho \omega)}{\partial t}+\frac{\partial}{\partial x_{j}}\left(\rho u_{j} \omega\right)=\frac{\partial}{\partial x_{j}}\left(\mu_{e f} \frac{\partial \omega}{\partial x_{j}}\right)-\rho \beta \omega^{2}+C d_{\omega}+\alpha \frac{\rho}{\mu_{t}} P_{k},
\end{aligned}
$$

where $F_{i}$ - projections of the vector of mass forces on the coordinate axes; $p$ - hydrodynamic pressure; $k$ - kinetic energy of turbulent pulsations; $x_{j}$ - Cartesian coordinates; $u_{j}$ - projections of speed in the Cartesian coordinate system; $\mu_{e f}=\mu+\mu_{t}-$ effective viscosity; $\mu_{t}-$ turbulent viscosity; $\mu$ - molecular viscosity; $P_{k}$ - generation member; $C d_{\omega}-$ cross member; $\alpha, \beta, \beta^{*}-$ empirical constants of the SST model; $t$ - time; $\omega$ - frequency of turbulent pulsations.

In carrying out a numerical study, the following assumptions are made:

- flow at the input to the computational domain is axisymmetric;

- flow regime is stable;

- flow in the casing niche in the impeller does not affect the parameters of the main flow in the pump and its integral characteristics.

For the numerical experiment using the software product SolidWorks, three-dimensional liquid-body models of the impeller and pump casing are created (Fig. 9).

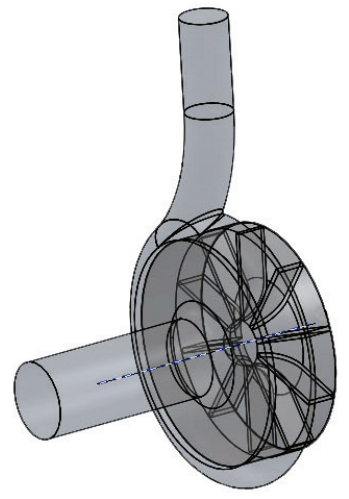

Fig. 9. 3 D liquid-body models

After the creation of the liquid-body models, the calculated grids are constructed (Fig. 10). A block-structured hexahedron grid is constructed for the impeller. A tetrahedron grid is structured for the pump body. Near the solid walls, several layers of prismatic cells are created, which made it possible to increase the resolution of the near-wall region to calculate the boundary layer. Based on the results of calculations, the variable's value $Y^{+}$is not more than 2, which confirms the adequacy of the use of the SST model of turbulence. The density of design grids is: for the impeller - 1200000 cells and 285000 knots, for the pump casing - 1500000 cells and 420000 knots.

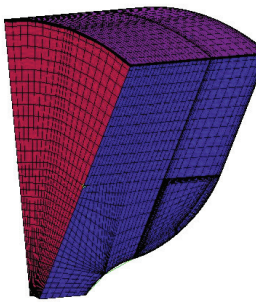

$a$

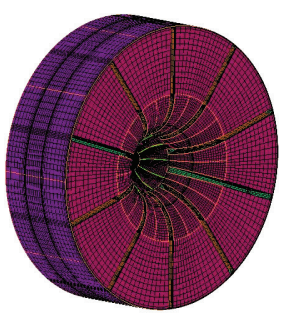

$b$

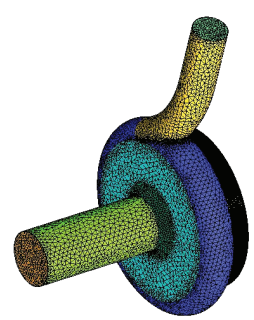

C
Fig. 10. Calculated grids:

$a$ - impeller element; $b$ - impeller; $c$ - pump casing

After generating the grids, CR is created in the Preprocessor (Fig. 11). The calculation region (CR) consisted of an impeller and pump casing, which combines an inlet pipe, a free chamber and an outlet nozzle. At the entrance to the calculation area, the mass flow rate $(G, \mathrm{~kg} / \mathrm{s})$ is set. For the turbulence parameters at the inlet, an average intensity level is specified. At the output from CR, the value of the static pressure $(p, \mathrm{MPa})$ is set. 


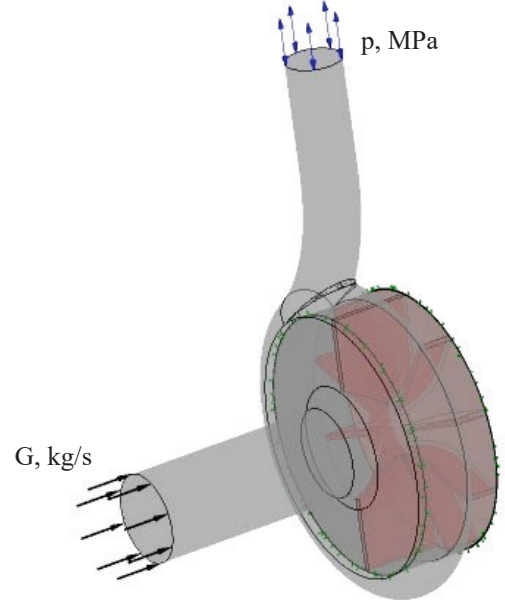

Fig. 11. Calculated region

The regions of the interface on the boundary of interaction between the rotor and stator elements were defined. The type of interface was indicated as «frozen rotor», which included time averaging [26].

As a result of numerical calculation, instantaneous values of velocities and pressures are obtained in each cell of the computational grid. To determine the integral values, it is carried out averaging over the mass flow.

5.3. Determination of technical level. 5.3.1. Nomenclature of quality indicators of pumping equipment. When determining the level of quality of pumping equipment, it is necessary to determine the nomenclature of quality indicators, which should be the same for the product and base sample being estimated.

When selecting quality indicators, the requirements of normative documents are taken as a basis [27-31]. In addition, the recommendations [32, 33] are taken into account.

Thus, the following nomenclature of quality indicators for a dynamic pump is established:

1) indicators of destination:

- feed;

- pressure;

- rotation frequency;

2) indicators of technical and energy efficiency:

- coefficient of efficiency;

- allowable cavitation stock;

- index of energy efficiency;

3) constructive and technological indicators:

- weight;

4) reliability indicators: the installed life (before overhaul or before write-off).

Thus, it is impossible to determine the generalized level of quality of a dynamic pump using the main indicator that would characterize this product. Therefore, these indicators are recommended to be determined by means of weighted averages.

5.3.2. Method for determining the level of quality of pumping equipment. To determine the level of quality of pumping equipment, it is recommended to use the Harrington method (the «desired function» method), which was proposed in [34] to estimate the quality of products by one key indicator that characterizes the quality of the products being estimated:

$$
d=e^{-\left(e^{-\gamma^{\prime}}\right)},
$$

where $d$-dimensionless quantity; $d$ - base of the natural logarithm; $y^{\prime}$ - equivalent of a natural value in the estimated quality score.

The advantage of this method is that the natural values of indicators with different dimensions mathematically convert to dimensionless quantities that have a qualitative content and give a quantitative estimate of the level of the indicator relative to its maximum permissible values. Using the values calculated for each indicator, it is possible to perform any mathematical operations for a comprehensive estimation of the quality of the object under study.

However, this method has some drawbacks:

- subjective determination of the nominal and the best limit values of the quality level;

- rejection of the whole set of natural values of the indicator inherent in this class of products, which leads to a distortion of the estimation of the complex (generalized) indicator [35].

The criteria for estimating the values of the generalized indicator of the quality level of pumping equipment are given in Table 1.

Table 1

Criteria for estimating a generalized indicator

\begin{tabular}{|c|c|}
\hline Estimate & The range of values of the generalized indicator \\
\hline Very good & $1-0.80$ \\
\hline Good & $0.80-0.63$ \\
\hline Satisfactorily & $0.63-0.37$ \\
\hline Bad & $0.37-0.20$ \\
\hline Very bad & $<0.20$ \\
\hline
\end{tabular}

To calculate the generalized index of the quality level of pumping equipment, it is suggested to use the method developed by the author of [36].

This method meets all the criteria for determining the generalized indicator:

1) it is necessary that the method should take into account the non-linear change in the effect when the various parameters that are considered are changed;

2) it is necessary to provide for joint accounting of not one, but several parameters;

3 ) it is desirable that the account of the influence of each of the parameters be independent. For this it is necessary that each of the parameters can be entered and output from the formula (with a quantitative estimation), without violating the integrity of the calculation;

4) it is desirable that the method's own errors be minimal.

$$
D=\sum_{i=1}^{m} \gamma_{i} \sqrt{\prod_{i=1}^{m} d_{i}^{\gamma_{i}}}
$$

where $\gamma_{i}$ - weight parameter of the i-th desirability; $B$ total number of indicators that characterize the quality of products. 
When calculating the $i$-th quality index of pumping equipment - the dimensionless value of the desirability level $\left(d_{i}\right)$ - the equivalent of the natural value of the estimated parameter $y_{i}^{\prime}$ is used. This value is recommended to be determined by the method of rational and nominal values.

When choosing the values of the minimum and rational quality parameters of the $i$-th indicator, it is necessary that the following requirements are met:

$$
y_{\text {rac }}>y_{n}, y_{n}>0, y_{\text {rac }}>0,
$$

where $\gamma_{n}$ i $\gamma_{\text {rac }}$ - the nominal and rational value of the $i$-th quality index of pumping equipment.

The nominal value of the parameter of $i$-th indicator of the pumping equipment should be planned based on the data of the base sample.

Thus, the generalized indicator of the quality level of pumping equipment can take a numerical value in the range $0<D \leq 1$. Analysis of these indicators makes it possible to identify common parameters that quantitatively can characterize the level of quality of pumping equipment.

The most complex in the calculations of the complex indicator according to the proposed method is the mechanism for determining the weight parameters that characterize the quality indicators of pumping equipment.

5.3.3. Expert estimations as a method of determining indicators that characterize the quality of products. During the work to determine the quality level of pumping equipment, it is very important to determine the parameters and indicators that comprehensively characterize the object of research. The purpose of the estimation should be formulated very clearly and quantitatively.

For the selection of indicators characterizing the quality of pumping equipment, it is recommended to use the expert method - «Method of full (double) pair matching».

The experience of using pair matching in expert methods shows that, due to the peculiarities of the human psyche, sometimes unconscious experts prefer, not because of the object of examination, which is more important, but rather to the one that is the first in the pair under consideration [37]. In order to prevent this, a double or pairwise comparison is carried out. To do this, all the cells of the pairwise matching matrix are used, that is, pairwise matching is done twice - the expert must put in each cell that relates to the two compared indicators, the number of the indicator that it considers more important. Thus, each pair of objects is mapped twice, and in different orders and after a certain period of time.

Let's give an algorithm for using this method.

The first stage of the expert estimation is the determination of the size of the expert group and the conduct of an expert survey.

To solve the problem of the size of the expert group, it is possible to use the device, which is used in the sample method of mathematical statistics to determine the sample size [38].

The number of the expert group is calculated by the formula [38]:

$$
n=\frac{0,04 d^{2}}{\overline{\Delta K}^{2}(1-P)},
$$

where $d$ - the scale of the measurement scale; $P$ - admissible value of the confidence probability with which the value of the collective peer review is determined. As a rule, take a level of significance $\alpha=0.05$ and then a confidence probability $P=(1-\alpha)=0.95 ; \overline{\Delta K}-$ the permissible value of the absolute error $(\Delta K)$ of the collective peer review. For further calculations it is recommended to accept $\overline{\Delta K}=(6$ or 7$)$.

The span of the measurement scale for the full (double) pair matching method is calculated by the formula:

$$
d=m-1,
$$

where $B$ - the number of selected indicators.

After the work on the formation of the expert group, coding factors and determining the opinions of experts is made (Table 2).

Table 2

Example of the expert group opinion analysis sheet

\begin{tabular}{|c|c|c|c|c|c|}
\hline \multicolumn{7}{|c|}{ No. of expert } \\
\hline No. of indicator & 1 & 2 & 3 & 4 & 5 \\
\hline 1 & 1 & 0 & 0 & 2 & 1 \\
\hline 2 & 2 & 1 & 1 & 2 & 2 \\
\hline 3 & 2 & 1 & 1 & 1 & 2 \\
\hline 4 & 0 & 0 & 1 & 1 & 0 \\
\hline 5 & 1 & 0 & 0 & 2 & 1 \\
\hline
\end{tabular}

Note: the preference of the $j$-th object in front of the $i$-th is indicated by the number 2 , the equivalence by the number 1 , the advantage of the $j$-th object before the $i$-th is the number 0 .

The second stage - calculation of weight coefficients of indicators is carried out under the formula:

$$
\gamma_{i}(1)=\sum_{i=1}^{n} \frac{F_{i j}}{n}, \quad i=1 \ldots n, j=1 \ldots m,
$$

where $F_{i j}$ - frequency of preference by the $i$-th expert to the $j$-th indicator;

$$
F_{i j}=\frac{K_{i j}}{C},
$$

where $K_{i j}$ - the number of advantages provided by the $i$-th expert to the $j$-th indicator; $C$ - total number of judgments of one expert is related to the number of $(B)$ comparisons [39]:

$$
C=B(B-1)
$$

The third stage is the determination of the consistency of opinions of the members of the expert group. Consistency of opinions of experts is expressed through the concordance coefficient [19]:

$$
W=\frac{3 S}{n^{2}\left(m^{3}-m\right)}
$$

where $S$ - the sum of the squares of the deviations of the sum of the advantages of the experts of each indicator from the average arithmetic advantage:

$$
S=\sum_{j=1}^{m}\left(\sum_{i=1}^{n} K_{i j}-\frac{1}{m} \sum_{j=1}^{m} \sum_{i=1}^{n} K_{i j}\right)^{2} .
$$


The consistency of experts is considered acceptable if the value of the concordance coefficient $W \geq 0.6$ [40]. The significance of the concordance coefficient of is estimated by the criterion $\chi^{2}$ :

$$
\chi^{2}=W \cdot n \cdot(m-1) .
$$

The concordance coefficient is statically significant if:

$$
\chi^{2}>\chi_{(1-\alpha), f}^{2}
$$

where $f$ - the number of freedom degree $f=(m-1) ; \alpha-$ significance level.

The value of $\chi_{0.95, f}^{2}$ are given in Table 3 .

Table 3

The values of criterion $\chi_{0.95, i}^{2}[41]$

\begin{tabular}{|c|c|c|c|c|c|c|c|c|c|c|c|}
\hline$f$ & 1 & 2 & 3 & 4 & 5 & 6 & 7 & 8 & 9 & 10 & 11 \\
\hline$\chi_{0.95, t}^{2}$ & 3.84 & 5.99 & 7.82 & 9.49 & 11.07 & 12.59 & 14.07 & 15.51 & 16.92 & 18.31 & 19.68 \\
\hline
\end{tabular}

If the expert opinion is inconsistent $(W<0.6)$, then one of the options for action is possible [40]:

- remove an expert whose opinion differs from the opinion of others;

- delete objects that cause a discrepancy;

- divide the experts into groups according to the consis-

tency of opinions and to conduct an analysis separately for each group;

- conduct a second round of expert surveys.

In this paper, to agree opinions of experts it is recommended to choose an action that involves the removal of an expert whose opinion is at variance with the opinion of other members of the expert group. To do this, it is necessary to do the following:

1. Calculate for all experts Spearman matrix of rank correlation coefficients $r_{i}$ between the number of advantages of the $i$-th expert of the $j$-th indicator and the average arithmetic advantages of other experts $\frac{1}{n} \sum_{i=1}^{n} K_{i j}$ :

$$
r_{i}=1-\frac{6 \sum_{i=1}^{m}\left(K_{i j}-\frac{1}{n} \sum_{i=1}^{n} K_{i j}\right)}{m\left(m^{2}-1\right)} .
$$

When $r_{i} \leq 0.5$ it is possible to assume that the estimations of this expert opinion are not correlated with the overall estimations and such expert is eliminated.

2. Conduct a review of the consistency of the views of the expert group after the removal of the selected expert.

The fourth stage is the refinement of the weight coefficients. To refine the values of the weight coefficients obtained by double pairwise comparison, one can use the method of successive approximations. The initial results are considered in this case as the first approximation. In the second approximation, they are used as weighting factors $G_{i}(2)$ of experts' judgments. The new results obtained with these weight coefficients taken into account, in the third approximation, are again considered as the weighting coefficients $G_{i}(3)$ of the judgments of the same experts, etc. According to the Perron-Frobenius theorem [42], under certain conditions that are satisfied in practice, this process converges, that is, the weighting coefficients are sent to some constant values, strictly reflect the relationship between the objects of expertise at the initial data set by the experts.

In this paper, refinements of the weight coefficients are proposed to be performed by the method of successive approximations, in which the measurement result $(\omega)$ in the approximation is defined as the mean square weighted.

Preliminary results $G_{i}(1)$ are determined by the formula:

$$
G_{j}(1)=\sum_{l=1}^{m} K_{j l},
$$

where $K_{j l}$ - the number of advantages of the j-th indicator by one expert $(l=1 \ldots m) ; G_{j}(1)$ - the result of measuring the $j$-th index in the first approximation.

The results of measuring the $j$-th index in the $(w)$ approximation will be [40]:

$$
G_{j}(w)=\sqrt{\left[\left(G_{1}(w-1)\right]^{2} \cdot K_{j 1}+\ldots+\left[\left(G_{m}(w-1)\right]^{2} \cdot K_{j m}\right.\right.},
$$

where $G_{j}(w-1)$ - the results of the measurement of the $j$-th indicator in the $(w-1)$ approximation.

The values of the weight coefficients in the (w) approximation are determined as:

$$
\gamma_{j}(\omega)=\frac{G_{j}(w)}{\sum_{j=1}^{m} G_{j}(w)}
$$

The process of refinement of values continues until the accuracy reaches the specified value, that is, until the following condition is fulfilled:

$$
\gamma_{j}(w)-\gamma_{j}(w-1) \leq \varepsilon,
$$

where $\varepsilon$ - given calculation accuracy, which is assumed [38]:

$$
\begin{aligned}
& \varepsilon=0.001 \text { at } 1<a \leq 1 ; \\
& \varepsilon=0.01 \text { at } a>5,
\end{aligned}
$$

where $a$ - coefficient, showing how many times the weight of the best of the indicators exceeds the weight of the worst indicator.

The fifth stage is exception is not important indicators. The nomenclature of indicators characterizing the quality of pumping equipment must satisfy the principles of a comprehensive estimation of their quality. This determines the availability in the nomenclature of quality indicators of pumping equipment of so-called critical indicators. The affiliation of indicators to the number of critical ones does not depend on the value of the coefficient of weight of this indicator, that is, the indicator can be relatively unimportant (with a low value of the weight coefficient) and at the same time critical.

The work on the elimination of low-value indicators begins after the indicators characterizing the critical properties of pumping equipment are determined.

Conditionally assume that the error with which the value of the quality index is calculated is affected only by the error in determining the value of the weighting coefficients. This means that the lower bound of the value of the relative error with which the value of the quality index is calculated is equal to the value (Table 4) [43]. 
According to Table 4 (with confidence probability $P=0.95)$ let's determine the lower bound of the relative error $e$ with which the values of the weight coefficients are determined by the expert method. in the pump head (10-12\%) and a corresponding increase in efficiency. At the same time, the optimal mode (the pump feed rate at the maximum efficiency value) remains practically unchanged.
Tahle 4

Lower level of relative еггог $e$

\begin{tabular}{|c|c|c|c|c|}
\hline $\begin{array}{c}\text { Number of } \\
\text { expert group }\end{array}$ & 7 & 8 & 9 & 10 \\
\hline $\begin{array}{l}\text { Lower bound of } \\
\text { relative error } \\
e \text { of collective } \\
\text { expert estimation }\end{array}$ & 0.18 & 0.17 & 0.16 & 0.15 \\
\hline
\end{tabular}

By summing the smallest values of the weight coefficients (in addition to the values of the weighting coefficients characterizing the critical exponents), unimportant indicators are determined. The procedure is then filled in until the condition is fulfilled:

$$
\sum_{j=1}^{m^{\prime}} \gamma_{\min j} \leq e
$$

where $m^{\prime}$ - the number of indicators that have the lowest values of weighting coefficients.

In the case of determining the weight coefficients by the expert method, the weight coefficients are calculated from expression (25).

\section{Research results}

During the physical tests, a multifactorial experiment is planned, which allowed obtaining separate estimates of the influence of each factor. Based on the analysis of a priori information, factors influencing the response function, their levels and variation intervals are selected. As parameters of variation, the following constructive factors are chosen:

- number of blades extended into the free chamber of the pump;

- width of the blades extended into the free chamber of the pump (from zero to the maximum value); - angle of installation of the leading edge of the blade, pushed into the free chamber.

Fig. 12-14 shows the characteristics of the experimental pump with a different number of blades pushed into the free chamber $(0,2,4)$.

The obtained experimental evidence shows that by slightly changing the geometry of the impeller (elongation of a part of the blades), it is possible to achieve an increase

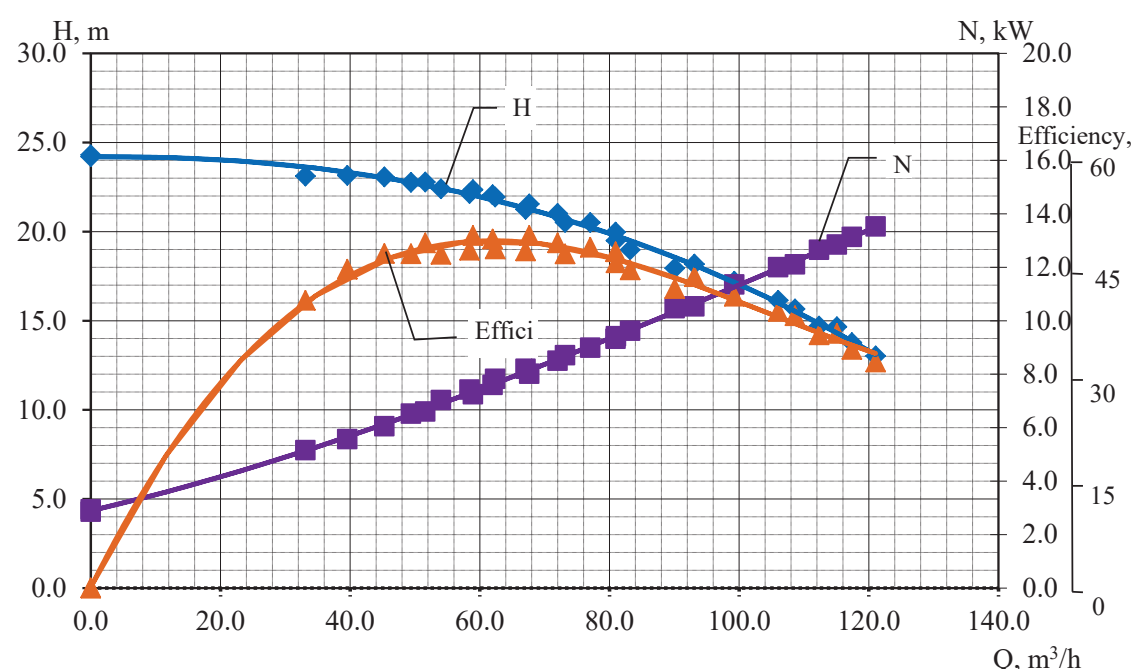

Fig. 12. Characteristics of the experimental pump with blades of the usual design: $H$ - pump head; $N$ - power

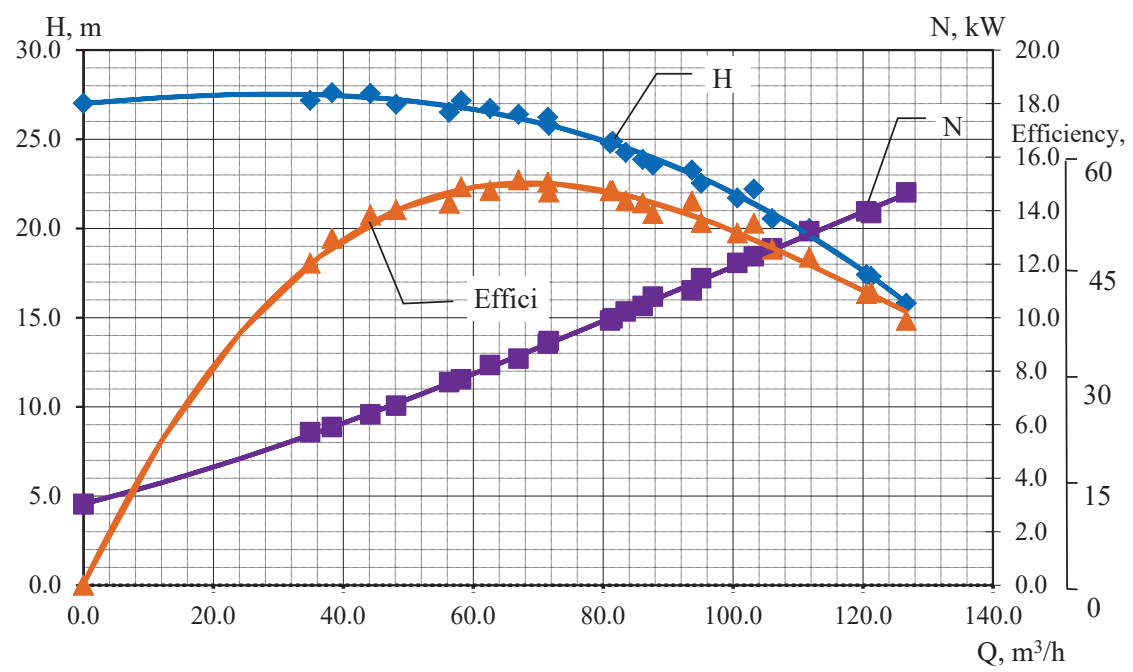

Fig. 13. Characteristics of the experimental pump with two extended blades: $H$ - pump head; $N$ - power

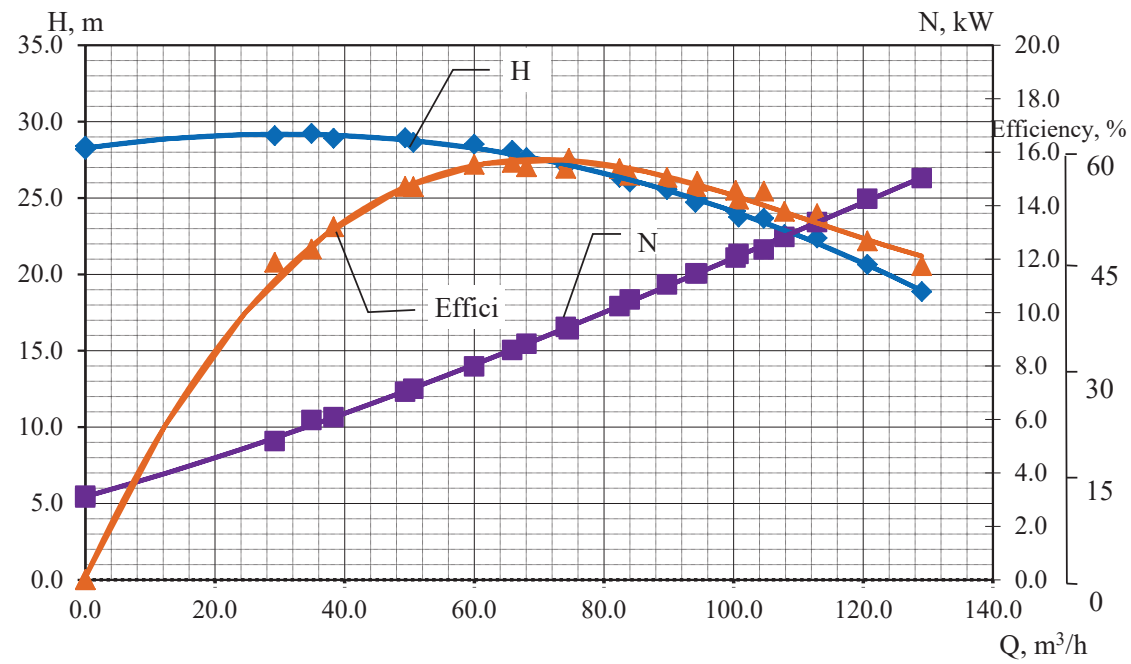

Fig. 14. Characteristics of the experimental pump with four extended blades: $H$ - pump head; $N$ - power 
The results of the calculation of the technical level indicate that the technical level of the designed pump increased by $12 \%$ compared to the analog pump.

\section{SWOT analysis of research results}

Strengths. In comparison with analogues, the investigated TFPs with blades extended into the free chamber have the following advantages: increase of pump head, increase of efficiency. In addition, it should be noted that the modernization of existing equipment is very simple: by welding flat plates of a part of the blades with subsequent turning and bench (or just bench) processing.

Weaknesses. The weaknesses of the proposed construction include: the increase in the power consumption of the pump; increase in the hydrodynamic forces acting on the pump rotor; reduction of the maximum permissible size of solid impurities in the pumped liquid.

Opportunities. The application of the proposed method of changing the geometry of the TFP impeller allows one to create on the same pump base several pumping units with different headings for better coordination of their operation with the network.

In addition, this method allows to change the operating parameters of the pump so that its operating point corresponds to the maximum value of the efficiency. Thus, the energy savings that are consumed by the enterprise for driving the pumps will be achieved.

Threats. When using the proposed method of modernization of pumping equipment, it is necessary to carry out additional calculations of the power consumed by the pump and, if necessary, to purchase new drive motors.

\section{Conclusions}

1. As a result of the analysis of previous studies, it is found that the most appropriate way to influence the geometry of the TFP flowing part is changing the geometric parameters of the impeller (extending the blades into a free chamber). It is taken into account that the extension of all the blades significantly affects the maximum permissible size of pumped solid impurities in the liquid. Therefore, it is proposed to put only a part of the blades into the free chamber.

2. The possibility of using various models of turbulence for numerical calculation is considered. It is concluded that the SST model of turbulence is most suitable for calculating the flow in the TFP. Three-dimensional liquidbody model of the TFP flowing part are constructed. The numerical experiment is carried out.

3. An experimental stand is created for the physical experiment. Experimental impellers with various combinations of geometric parameters (number of blades, blade width) are made. The pressure and energy characteristics of the experimental pump under study are obtained.

4. The use of Harrington's method for estimating the quality of products by one key indicator is justified. With the help of an expert method, the weight coefficients of quality indicators are determined. The integral quality index of a modernized pump and an analog pump is calculated. It is established that the technical level of the designed pump has increased by $12 \%$ compared to the analog pump.

\section{References}

1. German V. F., Kovalev I. A., Kotenko A. I. Svobodnovikhrevye nasosy / ed. by Gusaka A. G. Sumy: Sumskiy gosudarstvennyy universitet, 2013. 159 p.

2. German V. F. Sozdanie i issledovanie stochnomassnykh svobodnovikhrevykh nasosov povyshennoy ekonomichnosti: Thesis of Doctor of Technical Sciences. Sumy, 1984. 154 p

3. Wegener G. Einsatz von Turo-Pumpen in der Industrie // Allgemeine Papier, Rundschau. 1968. No. 40. P. 1208-1210.

4. Sapozhnikov S. V. Uchet gazovoy sostavlyayushhey perekachivaemoy sredy pri opredelenii konstruktsii i rabochey kharakteristiki dinamicheskogo nasosa: PhD thesis. Sumy, 2002. 206 p.

5. Krishtop I. V., German V. F., Gusak A. G. Svobodnovikhrevye nasosy tipa «Turo». Perspektivy primeneniya v khimicheskikh ustanovkakh // Khimichna promislovist' Ukraini. 2015. Vol. 2, No. 127. P. 40-44.

6. Vashist B. V., German V. F Osobennosti ispol'zovaniya svobodnovikhrevykh nasosov konstruktivnoy skhemy «Wemco». URL: http://www.essuir.sumdu.edu.ua/bitstream/123456789/31425/1/ Vashust.pdf

7. Rütschi K. Die Arbeitweise von Freistrompumpen // Bauzeitung, Schweiz. 1968. Vol. 86, No. 32. P. 575-582.

8. Yakhnenko S. M. Gidrodinamicheskie aspekty blochno-modul'nogo konstruirovaniya dinamicheskikh nasosov: Thesis of Doctor of Technical Sciences. Sumy, 2003. 210 p.

9. German V. F., Kochevskiy A. N., Shhelyaev A. E. Vliyanie razlichnykh sposobov dovodki rabochego kolesa na kartinu techeniya i kharakteristiki svobodnovikhrevogo nasosa tipa TURO // Problemy mashinostroeniya. 2007. Vol. 10, No. 1. P. 24-31.

10. Zarzycki M., Rokita J., Morzyński S. Badania pompy kretnej o swobodnym przepływie produkowanej seryjme // Zesz. nauk. PSJ. 1974. No. 425. P. 103-119.

11. Bak E. Ekonomiczne przeslanki stosowania pomp o swobodnym przeplywie do podnoszenia mieszaniny wody i cial stalych // Prace Instytutu Maszyn Przeplywowych. 1975. P. 235-241.

12. Grabow G. Einflub der Beschaufelung auf das Kennlinienverhalten von Freistrompumpen // Pumpen und Verdichter. 1972. No. 2. P. $18-21$

13. Aoki M. Studies on the Vortex Pump: 2nd Report, Pump Performance // Bulletin of JSME. 1983. Vol. 26, No. 213. P. 394-398. doi: http://doi.org/10.1299/jsme1958.26.394

14. Svobodnovikhrevoy nasos: A. s. 1236175 SSSR. MKI F 04 D 7/04 Vertyachikh A. V., German V. F., Kovalev I. A. No. 3780994/25-06; declareted: 15.08.84; published: 07.06.86, Bul. No. 21.

15. GOST 8.586.1-5-2005. Izmerenie raskhoda i kolichestva zhidkostey i gazov s pomoshh'yu standartnykh suzhayushhikh ustroystv. Moscow: Standartinform, 2007. 87 p.

16. RD 50-213-8. Pravila izmereniya raskhoda gazov i zhidkostey standartnymi suzhayushhimi ustroystvami. Moscow: Izd-vo standartov, 1982. $320 \mathrm{p}$.

17. GOST 6134-2007 (ISO 9906:1999). Nasosy dinamicheskie. Metody ispytaniy. Moscow: Standartinform, 2008. 94 p.

18. Loytsyanskiy L. G. Mekhanika zhidkosti i gaza: textbook. Moscow: Nauka. gl. red. fiz.-mat. lit., 1987. 840 p.

19. Krishtop I. V. Usovershenstvovannoe otvodyashhee ustroystvo svobodnovikhrevogo nasosa s uluchshennymi gidravlicheskimi pokazatelyami: Thesis of Doctor of Technical Sciences. Sumy, 2015. 188 p.

20. ANSYS CFX-Solver Theory Guide // ANSYS, Inc. 2006. URL: http://product.caenet.cn/Uploadfiles/128724372509866250200 81129090050986.pdf

21. ANSYS CFX-Solver Modeling Guide // ANSYS, Inc. 2009. URL: http://www.ebah.com.br/content/ABAAABJVwAC/ansys-cfxsolver-modeling-guide-12

22. Kochevskiy A. N., Nenya V. G. Sovremennyy pokhod k modelirovaniyu i raschetu techeniy zhidkosti v lopastnykh gidromashinakh // Visnik SumDU. 2003. No. 13 (59). P. 178-187.

23. Khitrykh D. ANSYS Turbo: Skvoznaya tekhnologiya proektirovaniya lopatochnykh mashin // ANSYS Solution. 2007. No. 6. P. 31-37.

24. Khitrykh D. ANSYS Turbo: Obzor modeley turbulentnosti // ANSYS Solution. 2005. No. 1. P. 9-11. 
25. Simulation of flow inside an axial-flow pump with adjustable guide vanes / Kochevsky A. N. et al. // Proceedings of FEDSM2005 ASME Fluids Engineering Division Summer Meeting and Exhibition. Houston, 2005. P. 412-423.

26. ANSYS CFX 11.0 Solver Theory. Release 11.0. 2008. 261 p. URL: http://www.ansys.com

27. GOST 4.118-84. Sistema pokazateley kachestva produktsii. Oborudovanie nasosnoe. Nomenklatura osnovnykh pokazateley. URL: http://docs.cntd.ru/document/1200004086

28. RD 26-06-57-86. Metodika otsenki tekhnicheskogo urovnya i kachestva produktsii.

29. BS EN 16297-1:2012. Pumps. Rotodynamic pumps. Glandless circulators. General requirements and procedures for testing and calculation of energy efficiency index (EEI). URL: https:// shop.bsigroup.com/ProductDetail/?pid=000000000030245022

30. BS EN 16297-2:2012. Pumps. Rotodynamic pumps. Glandless circulators. Calculation of energy efficiency index (EEI) for standalone circulators. URL: https://shop.bsigroup.com/ ProductDetail/?pid $=000000000030245025$

31. BS EN 16297-3:2012. Pumps. Rotodynamic pumps. Glandless circulators. Energy efficiency index (EEI) for circulators integrated in products. URL: https://shop.bsigroup.com/ProductDetail/?pid=000000000030245028

32. REHLAMENT KOMISII (IeC) No. 278/2009 vid 6 kvitnia 2009 r. pro vykonannia Dyrektyvy 2005/32/IeC Yevropeiskoho Parlamentu i Rady stosovno vymoh ekodyzainu dlia spozhyvannia elektroenerhii v rezhymi bez navantazhennia i serednoho aktyvnoho koefitsiientu korysnoi dii zovnishnikh dzherel zhyvlennia. 2009. URL: old.minjust.gov.ua/file/32559.docx

33. REHLAMENT (IeC) No. 641/2009 vid 22 lypnia 2009 roku pro vykonannia Dyrektyvy 2005/32/IeC Yevropeiskoho Parlamentu ta Rady stosovno ekodyzainu dlia bezzashchilnykovykh avtonomnykh tsyrkuliatsiinykh nasosiv ta bezzashchilnykovykh tsyrkuliatsiinykh nasosiv, intehrovanykh u prystroi. 2009.

34. Harington E. C. The Desirability Function // Industrial Quality Control. 1965. Vol. 21, No. 10. P. 494-498.

35. Evko L. S. Otsenka urovnya pokazateley kachestva kompressorov: Obzornaya informatsiya. Moscow: TSINTIKHIMNEFTEMASH, 1981. $25 \mathrm{p}$
36. Zharkov Yu., Tsitsiliano O. Optimizatsiya kriteriev raboty organov otsenki sootvetstviya s ispol'zovaniem metoda Kharringtona / Standartizatsiya, sertifikatsiya, yakist'. 2004. No. 4. P. 36-38.

37. Fedyukin V. K. Upravlenie kachestvom protsessov. Saint Petersburg: Piter, 2004. 208 p.

38. Azgal'dov G. G. Teoriya i praktika otsenki kachestva tovarov (osnovy kvalimetrii). Mosocw: Ekonomika, 1982. 256 p.

39. Ushakov I. E., Shishkin I. F. Prikladnaya metrologiya: textbook. Saint Petersburg: SZTU, 2002. 116 p.

40. Korn G., Korn T. Spravochnik po matematike (dlya nauchnykh rabotnikov i inzhenerov). Moscow: Izdatel'stvo «Nauka», 1974. 832 p.

41. Lapach S. N., Chubenko A. V., Babich P. N. Statisticheskie metody v mediko-biologicheskikh issledovaniyakh s ispol'zovaniem Excel. Kyiv: MORION, 2001. 408 p.

42. Khamkhanova D. N. Teoreticheskie osnovy obespecheniya edinstva ekspertnykh izmereniy. Ulan-Ude: Izd-vo VSGTU, 2006. 170 p.

43. Azgal'dov G. G. Kvalimetriya v arkhitekturno-stroitel'nom proektirovanii. Moscow: Stroyizdat, 1989. 264 p.

Panchenko Vitalii, Senior Lecturer, Department of Applied Fluid Aeromechanics, Sumy State University, Ukraine, e-mail: pan_va@ukr.net, ORCID: http://orcid.org/0000-0001-9228-4888

Ivchenko Aleksandr, PhD, Assistant Professor, Department of Manufacturing Engineering, Machines and Tools, Sumy State University, Ukraine, e-mail: o.ivchenko@tmvi.sumdu.edu.ua, ORCID: https:// orcid.org/0000-0002-4274-7693

Dynnyk Oksana, PhD, Assistant Professor, Department of Electronic Devices and Automation, Konotop Institute of Sumy State University, Konotop, Ukraine, e-mail: odkonotop39@gmail.com, ORCID: https://orcid.org/0000-0002-1221-2065

Drach Olga, PhD, Senior Lecturer, Department of fundamental and general scientific disciplines, Konotop Institute of Sumy State University, Konotop, Ukraine, e-mail: olgadrachved@ukr.net, ORCID: https://orcid.org/0000-0002-0315-1416 